\title{
Ortaöğretim Muhasebe Eğitiminde Uygulanan Meslek Derslerinin Sektör Beklentilerini Karşılama ve Öğrenim Düzeyi Üzerine Erzurum İlinde Bir Araştırma*
}

Fatih Coşkun ERTAŞ* Abdurrahim ŞİMŞEK ${ }^{* *}$

\section{ÖZET}

Hemen hemen her alanda muhasebe birimine olan ihtiyaç, muhasebe ĕgitiminin önemini artırmaktadır. Ekonomik gelişmeler, paralelinde donanımlı meslek mensuplarını gerektirmektedir. Meslek liseleri de muhasebe alanında temel eğitimin verildiği kurumlar olması dolayısı ile eğitim sisteminde önemli bir yer tutmaktadır. Mesleki ĕgitim, sektörün ihtiyaç duyduğu ara elemanı sağlama konusunda çok önemli bir görev üstlenmektedir. $\mathrm{Bu}$ nedenle meslek ĕgitiminde verilen dersler sektörün beklentilerini karşılamalı ve istenilen şartlardabireyler yetiştirmelidir.

Çalışmamızda işkur.gov.tr ve kariyer.net sitelerindeki yaklaşık 1400iş ilanı incelenmiş ve lise mezunu düzeyindeki muhasebe meslek elemanlarında aranan şartlar belirlenmiştir. Muhasebe eğitiminde verilen dersler ve sektörün meslek elemanlarında aradıkları şartlar karşılaştırılmıştır. Ayrıca verilen derslerin öğrenciler tarafindan ne ölçüde ögrenildiği belirlenmeye çalışılmıştır.

Anahtar Kelimeler: Muhasebe Eğitimi, Meslek liseleri, Ders programları, Mesleki ve Teknik Eğitim.

JEL Sınıflandırması: M40, M41.

\section{A Research In Erzurum on Level Of Meet The Sector Expectations Of Professional} Courses Applied In High School Accounting Education And Learning Level

\section{ABSTRACT}

The need for accounting in all fields is increasing the importance of accounting education. Economic developments require well-equipped professionals. Vocational school shave an important place in the education system because it is the institutions where basic education and undertakes a very important task because it is provides the necessary skills to industry. Therefore education given to the students should meet the expectations of the industry.

In our work, about 1400 job advertisements in işkur.gov.tr, kariyer.net sites were examined and conditions for vocational schools graduates are determined. Lectures given in accounting education and the requirements of the industry are compared. In addition, it was tried to determine to what extent the courses were be learned by the students.

Keywords: Accounting Education, Curriculum, Vocationaland Technical Education.

Jel Classification: M40, M41.

\footnotetext{
* Makale Gönderim Tarihi: 07.05.2019, Makale Kabul Tarihi: 04.07.2019, Makale Türü: Araştırma Makalesi

* Prof. Dr., Atatürk Üniversitesi, İktisadi ve İdari Bilimler Fakültesi, fatihcoskun.ertas@atauni.edu.tr, Orcid ID: 0000-0002-2632-9694.

** Atatürk Üniversitesi, İktisadi ve İdari Bilimler Fakültesi,abdurrahimsimsek84@gmail.com, Orcid ID: 00000002-7317-1535.
} 


\section{GíRiş}

Ülkelerin en önemli zenginliği genç nüfusudur. Kalkınmış ülkeler genç nüfuslarını eğitmek ve nitelikli bireyler yetiştirmek için büyük maliyetlere katlanmaktadır. Çünkü günümüz rekabet ortamında insan kaynaklarının etkili ve verimli kullanılması ülkelere büyük bir avantaj sağlamıştır. Nitekim gelişmişlik ve eğitim harcamalarının paralellik göstermesi bunun bir göstergesidir. Gelecekte gerek işsizliğin azaltılması, gerekse ihtiyaç duyulan yetişmiş personelin ve sürdürülebilir ekonomik ve sosyal kalkınmanın sağlanması amacıyla genç bireylere yeterli ve kaliteli bir eğitim sunulması gerekmektedir. Son yıllarda ülkemizde eğitim alanında ciddi atılımlar yapılmış ve eğitime bütçeden ciddi paylar ayrılmaya başlanmıştır. Bu gelişmelerden mesleki eğitimde payını almış ve ülke gelişmişliği açısından büyük bir önem arz eden mesleki eğitim alanında da ciddi adımlar atılmıştır.

Küresel değişmelere ve gelişmelere uygun olarak planlanmış mesleki ve teknik eğitim insan merkezli kalkınmada kaçınılmaz bir zorunluluktur. Mesleki eğitim içerisinde iktisadi kalkınma açısından önemli olan ve ihtiyaç duyulan muhasebe ve finansman elemanının eğitilmesi ve ihtiyaç duyulan sektörlere kazandırılması da elzem bir durum haline gelmektedir. Bu bağlamda meslek liseleri, geleceğin ihtiyaç duyulan iş gücünü yetiştirmesi açısından çok önemli bir işlevi yerine getirmektedir. Ancak verilen eğitimin kaliteli ve ihtiyaçları karşılayabilir olması, verilen ders içeriklerinin beklentileri karşılaması ile mümkün olacaktır. İhtiyaç duyulan derslerin ve konuların müfredatta olmaması ve ya eksik olması, müfredatın aşırı yoğun ve yorucu olması, hedeflenen amaçlara hizmet etmemesi, öğrenci seviyesine uygun olmaması eğitimin başarısını düşürmekte ve yetişen meslek mensuplarının istenen şartlara sahip olmamasına yol açmaktadır.

Araştırmamızda sektörün beklentileri ve orta öğretim meslek liselerinde verilen muhasebe dersleri ve içerikleriarasında karşılaştırma yapılacak ve mevcut durumun sektör beklentilerini karşılayıp karşılamadığı ve bunların öğrenciler tarafından etkin öğrenilip öğrenilmediği incelenecektir.

\section{2. ÜLKEMİZDE MESLEKİ EĞİTIM TARİHi}

Mesleki eğitim bireylere bir meslek mensubunun sahip olması gereken bilgi ve becerileri kazandırmaya ve geliştirmeye yönelik eğitimlerdir. Bu eğitimlerle bireylerin teorik ve pratik eğitimler yoluyla bilgi ve becerilerinin geliştirilmesi hedeflenmektedir. (Erol ve Erkan, 2008:286)

Ülkemizde mesleki eğitim 12. Yüzyıldan 18. Yüzyılın sonlarına kadar geleneksel usta çırak ilişkisi ile devam etmiş̧tir. Selçuklularda mesleki eğitim "Ahilik" adlı meslek teşkilatları ile, Osmanlılar döneminde "Lonca" ve "Gedik" teşkilatları ileyapılmıştır. Osmanlı döneminde yetim, öksüz, gariban Müslüman ve gayri Müslim kişilerin temel eğitim almaları ve meslek kazanmaları amacıyla "islahhane" adı altında çeşitli sanat okulları açılmıştır.( Şişman,2008:32)

Tuna valisi Mithat Paşa 1860 yılında Niş’te, 1864 yılında Rusçuk ve Sofya'da Mesleki Teknik Öğretim kurumlarının temeli sayılan çeşitli ıslahhaneler açmıştır. Tanzimat'tan Cumhuriyet'e kadar erkek ve kız teknik okulları, ticaret okulları, memur okulları, ziraat ve orman okulları açılmıştır. 
1860'l1 y1llardan sonra ise mesleki eğitim örgün eğitim kurumlarında verilmeye başlanmıştır. Cumhuriyet ile beraber mesleki eğitim artık devlet politikası haline gelmiştir. 1927 yılında Milli Eğitim Bakanlığı'nın görev ve hizmet alanına alınan mesleki eğitim 1933 yılında bakanlık bünyesinde kurulan Mesleki ve Teknik Tedrisat Umum Müdürlüğü tarafından idare edilmiştir. Müdürlük 1941'de Mesleki ve Teknik Öğretim Müsteşarlığ1, 1960'da Erkek Teknik ÖğretimGenel Müdürlüğü, Kız Teknik Öğretim Genel Müdürlüğü, Ticaret Öğretimi GenelMüdürlüğü olarak yeniden teşkilatlandırılmıştır.

1992'de Erkek Teknik Öğretim Genel Müdürlüğü, K1z Teknik Öğretim GenelMüdürlüğü, Ticaret ve Turizm Öğretimi Genel Müdürlüğü, Sağlık İşleri Dairesi Başkanlığı,Çıraklık, Mesleki ve Teknik Eğitimi Geliştirme ve Yaygınlaştırma Dairesi Başkanlığı, EğitimiAraştırma ve Geliştirme Dairesi Başkanlığı kurulmuş ve 2011 yılında birimler Mesleki ve Teknik Eğitim Genel Müdürlügü (MTEGM) adı altında birleştirilmiştir. Yaygın mesleki eğitim ile açık öğretim kurumları da Hayat Boyu Öğrenme Genel Müdürlüğü (HBÖGM) bünyesinde toplanmıştır. (http://mtegm.meb.gov.tr/meb_iys_dosyalar/2016_07/29122004_mte_stareji_belgesi_2014_2 018_1.pdf, 2018 )

\section{3. ÜLKEMIZDE ORTAÖĞRETIM DÜZEYINNDE MUHASEBE EĞİTIMI}

Günümüz rekabet ortamında üstünlük sağlamanın anahtarı ülkelerin en önemli kaynağı olan insanı etkili ve verimli kullanmasıdır. Bu anahtarı sağlayacak ve ülkelere yetişmiş insan gücü oluşturacak araç ise eğitim kurumlarıdır. Artık ülkelerin gelişmişlik düzeylerinin ifadesinde sadece kişi başına düşen milli gelir değil aynı zamanda nitelikli insan gücü oranları da bir gösterge oluşturmaktadır.( Hoşgörür, Gezgin, 2004:2)

1927 yılında Milli Eğitim Bakanlığı'nın görev ve hizmet alanına alınan mesleki eğitim "Ticaret Ortaokulları" olarak adlandırılan okullarda verilmeye başlanmış, belli bir süre eğitime ara verdikten sonra 1986 yılında Ticaret Meslek Liseleri bünyesinde tekrar eğitime başlamıştır. Ticaret meslek liselerinde 1986-1987 yıllarında 3308 sayılı Çıraklık ve Meslek Eğitim Kanununun yürürlüğe girmesi ile Muhasebe programı uygulanmaya başlanmıştır. 2002-2003 yıllarında ise Bilgisayarlı Muhasebe Dalı dahil edilmiştir. Günümüzde muhasebe eğitimi muhasebe ve finansman alanı, bilgisayarlı muhasebe, dış ticaret ofis hizmetleri ve finans ve borsa hizmetleri dalları olarak mesleki ve teknik eğitim merkezleri, mesleki ve teknik Anadolu liseleri, çok programlı Anadolu liseleri gibi mesleki eğitim veren kurumlarda verilmektedir. Muhasebe eğitiminin düzeylere göre beklenen genel ve özel amaçları aşağıdaki gibidir:

Tablo 1. Muhasebe Eğitiminin Amaçları

\begin{tabular}{|l|l|l|}
\hline Aşama & Genel Amaçlar & Özel Amaçlar \\
\hline Orta & Bilimsel ve teknolojik gelişmeler & Muhasebenin temel bilgi ve becerilerini, temel \\
Öğretim & doğrultusunda sektörün ihtiyaçlarını & yeterliklerini kazandırmak. Dalın gerektirdiği \\
Aşaması & karşılayacak mesleki nitelikleri kazanmış & mesleki yeterlikleri kazandırmak. \\
& nitelikli meslek elemanları yetiştirmektir. & \\
\hline
\end{tabular}

Kaynak: (Çaldağ vd., 2004:124) 
Ortaöğretim aşamasında verilen mesleki eğitim süreci aşağıdaki tabloda özetlenmiştir.

Tablo 2. Ortaöğretim Mesleki Eğitim Süreci

\begin{tabular}{|l|l|l|l|}
\hline \multirow{2}{*}{ 9. Sınıf } & 10.Sınıf & 11.Sınıf & \multicolumn{1}{|l|}{ 12.Sunıf } \\
\cline { 2 - 4 } & Mesleki Ve Teknik Ortaöğretim & Dal Eğitimi \\
\hline Ortak Genel Eğitim & Alan Eğitimi & Dal Eğitimi & \\
\hline
\end{tabular}

Kaynak:(http://mtegm.meb.gov.tr/meb_iys_dosyalar/2016_07/29122004_mte_stareji_belgesi_2014_2018_1.pdf

2018) Türkiye'de mesleki ve teknik eğitim strateji belgesi ve eylem planı 2004-2018

\section{LITERATÜR ÖZETI}

Muhasebe eğitimi üzerine yapılan araștırmalar incelendiğinde muhasebe eğitiminde bölüm tercihleri, ders müfredat ve saatlerinin öğrenci seviyesine uygunluğu, muhasebe eğitiminde kullanılan öğretim yöntemleri, öğrenci motivasyonlarını etkileyen etmenler, muhasebe eğitiminin teorik ve pratik olarak karşılaştırılması, muhasebe eğitiminden beklentiler, muhasebe eğitim seviyeleri, işletmede beceri eğitimi uygulaması, muhasebe eğitiminin tarihi üzerine araştırmalar yapılmıştır. Ancak araştırmalar genel olarak meslek yüksek okulları ve fakülte düzeyinde yapılmış lise düzeyinde araştırmalar daha sığ kalmıştır.

$\mathrm{Bu}$ çalışmada meslek lisesi mezunlarının sektörün beklentilerini karşılama düzeylerinin belirlenmesi amacıyla güncel veriler kullanılarak işverenlerin lise düzeyinde muhasebe mezunlarından beklentileri ve meslek lisesi muhasebe ders programları incelenerek karşılaştırma yapılmış, beklentileri karşılayan dersler ve verilen derslerin istenen şartları karşılama düzeyleri, eksiklikleri, aşırı tarafları üzerine araştırma yapılarak literatüre katkı sağlanmaya çalışılmıştır.

Muhasebe eğitimi üzerine çeşitli araştrrmalar mevcuttur.

Bonwell ve Eison (1991), muhasebe eğitiminde modern öğretim üzerine Cottell ve Milis (1993), muhasebe eğitiminde geleneksel eğitim üzerine çalışmalarda bulunmuşlardır.

Kalmış ve Yılmaz (2004), Kaya ve Daştan (2004), Sayın vd., (2005), muhasebe eğitiminde kullanılan öğretim yöntem ve tekniklerinin etkinliği, konuların ve derslerin anlaşılma düzeyleri incelenmiş ve kalitenin arttırılması ile ilgili önerilerde bulunmuşlardır.

Byrne ve Flood (2005), muhasebe eğitiminde öğrencilerin motivasyon ve beklentileri ile ilgili yaptığı çalışmada muhasebe eğitiminin başarısında ders programlarının önemi kadar öğrencilerin motivasyonunda önemli olduğunu belirtmiştir.

Bekçi vd. (2006) muhasebe mesleğinde bilgi teknolojilerinin ve muhasebe paket programlarının önemini vurgulayarak öğrencilerin bilgisayar paket programları derslerinin iş hayatlarında kendileri için önemli oldukları algısı taşıdığını ve dersi sevdiklerini belirtmiştir.

Zaif ve Ayanoğlu (2007) Muhasebe Eğitiminde Kalitenin Arttırılmasında Ders Programlarını Önemi ile ilgili yaptı̆̆ araştırmada işletme bölümünde okutulan derslerin yetersiz olduğunu ve kalitenin artması için işletme bölümlerinin yanı sıra muhasebe veya muhasebe ve finansman bölümlerinin açılması gerektiğini belirtmiştir. 
Cheng (2007) lisans düzeyinde işletme bölümü ders programları üzerine yaptığ “ “ Muhasebe Eğitiminde Kalitenin Arttırılmasında Ders Programlarının Önemi: Türkiye’de Bir İnceleme" isimli çalışmasında muhasebe eğitimi verenlerle, muhasebe eğitimini talep edenlerin beklentileri arasında bariz farklılıkların bulunduğunu belirtmiştir.

Mısırlığlu (2008) İngiltere'de öğretim ve öğrenme deneyimi üzerine yaptığ1 çalışmasında; öğrenciye verilecek olan bilgi, öğrencilerin ihtiyaçlarına göre ve disiplinler arası olması gerektiğini, derslerin ve ders programlarının öğrencilerin amaçlarını göz önünde bulundurarak hazırlanması gerektiğini belirtmiştir.

Şengel (2010), muhasebe eğitiminin değişik kurumlarda hangi düzeyde verildiğini araştırmış ve ülkemizde mesleğe hazırlık eğitimlerinin yıllar içinde çok önemli ve etkili bir seviyeye ulaştığını belirtmiştir.

Kırlığlu ve Gökgöz (2011), ticaret meslek liselerinde muhasebe eğitimi alan öğrencilerin stajyerlikte karşılaştıkları problemler ve çözüm önerileri üzerine yaptığı çalışmada okul tercihlerinin bilinçsiz yapıldığı, verilen eğitimin yetersiz olduğu, staj uygulamasının öğrencilerin mesleki açıdan yetişmelerine imkan vermediği, teorik eğitimin pratik uygulamaların karşılığı olmadığı, eğitimcilerin staj yerlerini yeterince denetlemedikleri, iş dosyalarına gereken önemin verilmediği, öğrencilerin alanları dışında çalıştırıldıkları, staj aşamasında 2 gün okul, 3 gün staj uygulamasının işyeri ve okula adaptasyon problemleri oluşturduğunu belirtmiştir.

Akbulut vd. (2014) meslek mensuplarının bakış açıları ile ticaret meslek liselerindeki muhasebe eğitimi incelenmiş ve meslek mensuplarının muhasebe eğitiminin mesleğe yönelik olarak zayıf bulduklarını ve eğitimin kalitesinin arttırılması için meslek elemanlarının daha aktif olmaları gerektiğini ve mesleki eğitimlerde meslek elemanlarının daha çok görüşlerini alınması gerektiğini ifade etmişlerdir.

Özkan ve Aksoy (2015), Ticaret Meslek Lisesi Muhasebe Bölümü Öğrencilerinin İşletmelerde Beceri Eğitimi Uygulaması üzerine Gaziantep İlinde yaptı̆̆ işletmelerde beceri eğitiminde karşılaşılan sorunları belirtilmiş ve bu sorunlara çözüm önerileri sunulmuştur. Erol ve Atmaca (2015), ticaret meslek liselerindeki muhasebe eğitiminin tarihi gelişimi üzerine bir araştırma yapmış ve muhasebe finansman alanında nitelikli eleman ihtiyacının gün geçtikçe arttığını ve muhasebe finansman elemanlarının iyi yetişmeleri gerektiğini ve ders programlarının sektörün ihtiyaçlarına cevap verecek yapılandırılması gerektiğini ifade etmiştir.

Çiftçi ve Çemrek (2018), Muğla ilindeki ticaret meslek liselerinde muhasebe eğitimi üzerine yaptığı araştırmada ders kitaplarının güncellenmemesinden dolayı içerik olarak yetersiz kaldığını, staj eğitiminin öğrenciye iş disiplini ve iş ahlakı kazandırdığını, teorik bilgiyi uygulamaya dönüştürdüğünü belirtmiştir. 


\section{MUHASEBE MESLEK LISESİ MEZUNLARINDAN BEKLENEN ÖZELLIKLLER}

Mesleki eğitimin amacı sosyal hayatta ihtiyaç duyulan, hedefler ve iş çevrelerinin talepleri doğrultusunda kalifiye elemanlar yetiştirmek amacıyla gerekli olan bilgi ve becerilerin verilmesi sürecidir. Nitekim 2014-2018 Türkiye Mesleki ve Teknik Eğitim Strateji Belgesi Ve Eylem Planında mesleki eğitimin amac1 "Sosyal ve ekonomik kalkınmaya destek veren, toplumun tüm kesimlerinin kendi ihtiyaçlarına uygun ögrenme firsatı bulduğu, iş ve meslek ahlakı değerleri olan, yenilikçi, istihdama hazırlayan, paydaşların etkin katılımı ile esnek ve geçirgen bir mesleki ve teknik eğitim sistemini oluşturmak" olarak tanımlanmış ve mesleki eğitimin vizyonu olarak sosyal ve ekonomik sektörler ile işbirliği içinde gerekli mesleki değerlere sahip, ekonomiye değer katan bireyler yetiştiren bir sistem oluşturmak ifadeedilmiştir.(http://mtegm.meb.gov.tr, 2018 )

Mesleki ve Teknik Eğitim Strateji Belgesi ve Eylem Planından da anlaşılacağı üzere işverenler, meslek odaları gibi mesleki eğitimin bir parçası olan taraflar paydaş olarak tanımlamış ve mesleki eğitimin planlanmasındaişverenlerin taleplerinin dikkate alınmasının önemli olduğunu vurgulamıştır.

$\mathrm{Bu}$ bağlamda işverenlerin meslek elemanı ihtiyaçlarının ve meslek elemanlarında aradıkları şartların belirlenmesi mesleki eğitimin planlamasında önem arz etmektedir. Lise düzeyinde mezuniyeti olan muhasebe personeli ihtiyacının ve aranan şartların belirlenmesi amaciyla kariyer.net ve işkuriş bulma siteleri incelenmiştir.

Lise mezuniyet düzeyinde ön muhasebe elemanı, muhasebe meslek elemanı, bilgisayarlı muhasebe elemanı, muhasebeci, muhasebe yardımcı elemanı gibi çeşitli iş pozisyonlarındaKariyer.net internet adresinden ve Türkiye İş Kurumu ( İŞKUR ) internet sitesi üzerinden yaklaşı 1400 ilan incelenmiş ve işverenlerin lise düzeyindemeslek elemanlarından bekledikleriözellikleraşağıdaki gibibelirlenmiştir.

Tablo 3. Meslek Lisesi Mezunu Kişilerde Aranan Genel Özellikler

\begin{tabular}{|ll|}
\hline Mesleki Bilgi Düzeyinde & Kişisel Gelişim Düzeyinde \\
\hline Muhasebe paket programı kullanabilme & İnsan ilişkilerinde güçlü ve empati kurabilen. \\
\hline Ofis programlarını iyi seviyede kullanabilme & Yeniliklere ve gelişime açı, \\
\hline Beyanname verebilme & Dikkatli ve analitik düşünebilen, \\
\hline Tek düzen hesap planına hakim & Prezantabl ve diksiyonu düzgün \\
\hline Genel muhasebe bilgisine sahip & Takım çalışmasına yatkın, \\
\hline Muhasebe süreçlerinde tecrübeli & Etkili iletişim yeteneği olan, \\
\hline Dönem sonu muhasebe işlemlerine hakim & Kendini iyi ifade edebilen \\
\hline
\end{tabular}

Kaynak: (https://www.kariyer.net/is-ilanlari, 2018 )(http://www.iskur.gov.tr/tr-tr/anasayfa.aspx, 2018 ) 
Tablo 4. Meslek Lisesi Mezunu Kişilerden Beklenen İş Tanımları

\section{Meslek elemanından beklenen iş tanımı}

Müşterilerin satış belgelerinin (Fatura, e-fatura, e-arşiv fatura, perakende satış fişi, vb.) muhasebeleştirilmesi

Mal ve hizmet alış belgelerinin (Alım faturaları, Alım e-faturaları, gider pusulaları, harcırah formları, dekontlar vb. her türlü yasal mali belge) muhasebeleştirilmesi,

Gelen fatura, dekont, makbuz, banka ekstreleri v.b. tüm belgeleri tasnif edilmesi, dosyalanması, muhasebe kayitlarının tutulması

Banka ve Kredi kartı hareketleri, Çek-senet ya da Nakit olarak yapılan tahsilâtların, ödemelerin muhasebeleştirilmesi

Personel dosyalarının hazırlanması ve personel giriş çıkış kontrollerinin yapılması, Personel Maaş hesaplamalarının yapılması, SGK bildirgelerinin verilmesi

Gelen, giden evrakların takibinin ve kaydının yapılması,

E-beyanname düzenlenmesi, E- fatura, E defter, $\mathbf{E}$ beyanname süreçlerine hakim

Cari hesap kayıtlarının gerçekleştirilmesi, cari hesap mutabakatlarının yapılması,

Dönem sonu muhasebe işlemlerinin yapılması,

Hesapların gerek kendi içinde, gerekse çalışılan kurumlarla (banka, alıcı, satıcı, kasa, çek, senet, vb. ) mutabakatının yapılması

Kaynak: (https://www.kariyer.net/is-ilanlari, 2018), (http://www.iskur.gov.tr/tr-tr/anasayfa.aspx, 2018 )

\section{MUHASEBE VE FINANSMAN EĞİTIMINDEVERILEN DERSLER}

Muhasebe ve finansman eğitimi işletmelerin kuruluşundan başlayarak faaliyetleri ile ilgili belgelerin kaydedilmesi, sınıflandırılması, analiz ve yorumlanması, raporlanması, dosyalanması, arşivlenmesi, diş ticaret işlemlerinin muhasebeleştirilmesi, üretim yapan işletmelerin maliyet, gider ve performans işlemlerinin yapılması gibi mali nitelikteki işlemleri ve finansman işlemlerini kapsamaktadır.

Meslek liselerinde verilen muhasebe eğitiminde iki tür ders programı mevcuttur. Bunlardan biri meslek programı, diğeri ise teknik programdır.Aşağıda meslek liselerinde muhasebe eğitiminde uygulanan meslek ve teknik programlarının ders programları verilmiştir. 
Tablo 5. 2018-2019 yılından itibaren 10. Siniflar, 11. siniflar ve 12. Sinıflar Mesleki ve Teknik Anadolu Lisesi Anadolu Meslek Programı Muhasebe Ve Finansman Alanı (Bil. Muh., Dış Tic. Ofis Hizmetleri, Finans Ve Borsa Hizmet Dalları) Haftalık Ders Çizelgesi

\begin{tabular}{|c|c|c|c|c|c|}
\hline $\begin{array}{l}\text { DERS } \\
\text { KATEGORILERI }\end{array}$ & DERSLER & 9.SINIF & 10.SINIF & $\begin{array}{l}11 . \\
\text { SINIF }\end{array}$ & $\begin{array}{l}12 . \\
\text { SINIF }\end{array}$ \\
\hline \multirow{14}{*}{$\begin{array}{l}\text { ORTAK } \\
\text { DERSLER }\end{array}$} & TÜRK DİLİ VE EDEBIYYATI (*) & 5 & 5 & 5 & 5 \\
\hline & $\begin{array}{l}\text { DİN KÜLTÜRÜ VE AHLÂK } \\
\text { BİLGİSI }\end{array}$ & 2 & 2 & 2 & 2 \\
\hline & TARİH & 2 & 2 & 2 & - \\
\hline & $\begin{array}{l}\text { T.C. İNKILÂP TARİHİ VE } \\
\text { ATATÜRKÇÜLÜK }\end{array}$ & - & - & - & 2 \\
\hline & COĞRAFYA & 2 & 2 & - & - \\
\hline & MATEMATİK & 6 & 5 & - & - \\
\hline & FİZİK & 2 & 2 & - & - \\
\hline & KİMYA & 2 & 2 & - & - \\
\hline & BİYOLOJİ & 2 & 2 & - & - \\
\hline & FELSEFE & - & 2 & 2 & - \\
\hline & YABANCI DİL & 5 & 2 & 2 & 2 \\
\hline & BEDEN EĞITIMIM & 2 & 2 & 2 & - \\
\hline & GÖRSEL SANATLAR & 2 & - & - & - \\
\hline & $\begin{array}{l}\text { SAĞLIK BİLGİSI VE TRAFIK } \\
\text { KÜLTÜRÜ }\end{array}$ & 1 & - & - & - \\
\hline \multicolumn{2}{|l|}{ TOPLAM } & 33 & 28 & 15 & 11 \\
\hline \multirow{5}{*}{$\begin{array}{l}\text { ALAN ORTAK } \\
\text { DERSLERİ }\end{array}$} & MESLEKİ GELIŞSiM & 2 & - & - & - \\
\hline & TEMEL MUHASEBE & - & 7 & - & - \\
\hline & STANDART TÜRK KLÂVYESİ & - & 3 & - & - \\
\hline & OFİ PROGRAMLARI & & 2 & & \\
\hline & MESLEKİ MATEMATIKK & & 2 & & \\
\hline \multirow{8}{*}{$\begin{array}{l}\text { ALAN DAL } \\
\text { DERSLERİ }\end{array}$} & $\begin{array}{l}\text { İŞLETMELERDE MESLEKİ } \\
\text { EĞİTİM }\end{array}$ & \multirow{8}{*}{-} & \multirow{8}{*}{ - } & \multirow{8}{*}{18} & \multirow{8}{*}{26} \\
\hline & GENEL MUHASEBE & & & & \\
\hline & BİLGİSAYARLI MUHASEBE & & & & \\
\hline & ŞİRKETLER MUHASEBESİ & & & & \\
\hline & MALIYET MUHASEBESİ & & & & \\
\hline & DIŞ TİCARET İŞLEMLERİ & & & & \\
\hline & DIŞ TİCARET MUHASEBESİ & & & & \\
\hline & DIŞ TİCARET MEVZUATI & & & & \\
\hline
\end{tabular}




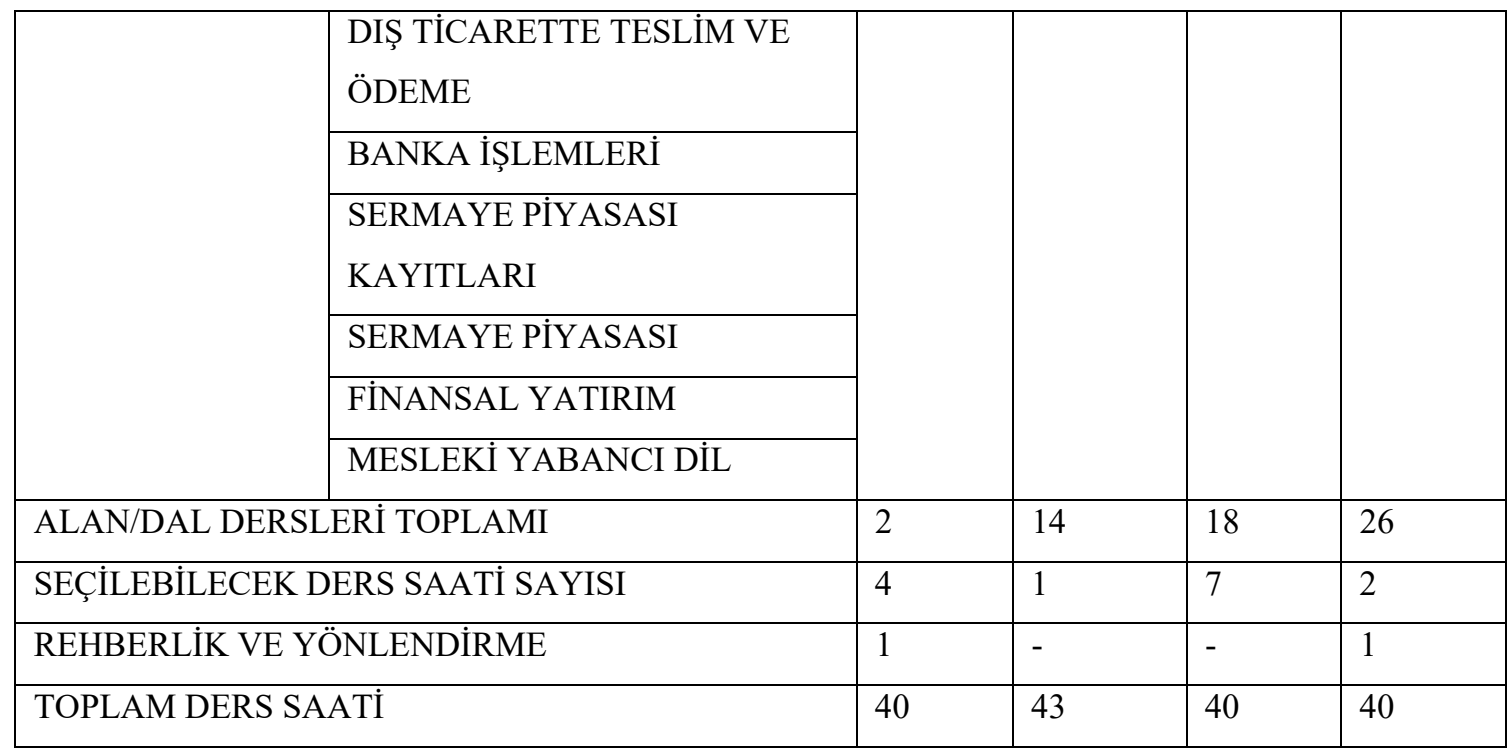

Kaynak:(http://www.megep.meb.gov.tr/?page=ogretimProgramlari, 2018 )

Tablo 6. 2018-2019 y1lından itibaren 10. Sinıflar, 11. sınıflar ve 12. Sinıflar Mesleki ve Teknik Anadolu Lisesi Anadolu Teknik Programı_Muhasebe Ve Finansman Alanı (Bil. Muh., Dış Tic. Ofiss Hizmetleri, Finans Ve Borsa Hizmet Dalları) Haftalık Ders Çizelgesi

\begin{tabular}{|c|c|c|c|c|c|}
\hline $\begin{array}{l}\text { DERS } \\
\text { KATEGORILERİ }\end{array}$ & DERSLER & 9.SINIF & 10.SINIF & $\begin{array}{l}11 . \\
\text { SINIF }\end{array}$ & $\begin{array}{l}12 . \\
\text { SINIF }\end{array}$ \\
\hline \multirow{14}{*}{$\begin{array}{l}\text { ORTAK } \\
\text { DERSLER }\end{array}$} & TÜRK DİLİ VE EDEBİYATI & 5 & 5 & 5 & 5 \\
\hline & $\begin{array}{l}\text { DİN KÜLTÜRÜ VE AHLÂK } \\
\text { BİLGİSI }\end{array}$ & 2 & 2 & 2 & 2 \\
\hline & TARİH & 2 & 2 & 2 & - \\
\hline & $\begin{array}{l}\text { T.C. İNKILÂP TARİHİ VE } \\
\text { ATATÜRKÇÜLÜK }\end{array}$ & - & - & - & 2 \\
\hline & COĞRAFYA & 2 & 2 & - & - \\
\hline & MATEMATİK & 6 & 6 & 6 & 6 \\
\hline & FİİK & 2 & 2 & 4 & 4 \\
\hline & KIMYA & 2 & 2 & 4 & 4 \\
\hline & BİYOLOJİ & 2 & 2 & - & - \\
\hline & FELSEFE & - & 2 & 2 & - \\
\hline & YABANCI DİL & 5 & 2 & 2 & 2 \\
\hline & BEDEN EĞİTiMİ & 2 & 2 & 2 & - \\
\hline & GÖRSEL SANATLAR & 2 & - & - & - \\
\hline & $\begin{array}{l}\text { SAĞLIK BİLGİSİ VE TRAFİK } \\
\text { KÜLTÜRÜ }\end{array}$ & 1 & - & - & - \\
\hline
\end{tabular}




\begin{tabular}{|c|c|c|c|c|c|}
\hline \multicolumn{2}{|l|}{ TOPLAM } & 33 & 29 & 29 & 25 \\
\hline \multirow{5}{*}{$\begin{array}{l}\text { ALAN ORTAK } \\
\text { DERSLERİ }\end{array}$} & MESLEKİ GELİŞİM & 2 & - & - & - \\
\hline & TEMEL MUHASEBE & - & 7 & - & - \\
\hline & STANDART TÜRK KLÂVYESİ & - & 3 & - & - \\
\hline & OFIS PROGRAMLARI & & 2 & & \\
\hline & MESLEKİ MATEMATİK & & 2 & & \\
\hline \multirow{14}{*}{$\begin{array}{l}\text { ALAN DAL } \\
\text { DERSLERİ }\end{array}$} & GENEL MUHASEBE & \multirow{14}{*}{-} & \multirow{14}{*}{-} & \multirow{14}{*}{7} & \multirow{14}{*}{13} \\
\hline & BİLGİSAYARLI MUHASEBE & & & & \\
\hline & ŞİRKETLER MUHASEBESİ & & & & \\
\hline & MALIYET MUHASEBESİ & & & & \\
\hline & DIŞ TİCARET İŞLEMLERİ & & & & \\
\hline & DIŞ TİCARET MUHASEBESİ & & & & \\
\hline & DIȘ TİCARET MEVZUATI & & & & \\
\hline & $\begin{array}{l}\text { DIŞ TİCARETTE TESLİM VE } \\
\text { ÖDEME }\end{array}$ & & & & \\
\hline & BANKA İŞLEMLERİ & & & & \\
\hline & SERMAYE PİYASASI & & & & \\
\hline & KAYITLARI & & & & \\
\hline & SERMAYE PIYYASASI & & & & \\
\hline & FINANSAL YATIRIM & & & & \\
\hline & MESLEKİ YABANCI DİL & & & & \\
\hline \multicolumn{2}{|c|}{ ALAN/DAL DERSLERİ TOPLAMI } & 2 & 14 & 7 & 13 \\
\hline \multicolumn{2}{|c|}{ SEÇİLEBİLECEK DERS SAATİ SAYISI } & 4 & 1 & 4 & 1 \\
\hline \multicolumn{2}{|c|}{ REHBERLİK VE YÖNLENDİRME } & 1 & - & - & 1 \\
\hline \multicolumn{2}{|c|}{ TOPLAM DERS SAATİ } & 40 & 44 & 40 & 40 \\
\hline
\end{tabular}

Kaynak:(http://www.megep.meb.gov.tr/?page=ogretimProgramlari,2018 )

Meslek liselerinde verilen muhasebe eğitiminde meslek ve teknik program ayrımı 2018-2019 eğitim öğretim yılından itibaren uygulanacaktır. Daha önceki senelerde bu tür bir ayrım yapılmayarak tek bir ders programı uygulanmaktaydı. Verilen ders programları incelendiğinde meslek ve teknik programlarınınverilecek meslek dersleri ve kültür dersleri ( matematik, edebiyat, tarih, coğrafya vb.) açısından farklılaştıkları görülmektedir. Örneğin meslek programlarında okutulacak toplam matematik dersi 11 saat iken ve 11. ve 12 . Sinıflarda yer almazken (sadece 9 ve 10. sinıflarda), teknik programlarda matematik dersi tüm sinıf düzeylerinde $(9,10,11$ ve 12 . siniflarda) ve toplam 24 saat verilmektedir. Yine fizik ve kimya dersleri meslek programlarında sadece 9 ve 10. siniflarda 4 er saat verilmekte iken, teknik programlarda tüm sinıf düzeylerinde ve toplamda 12 şer saat verilmektedir. Meslek dersleri açısından incelendiğinde ise meslek programlarında 11 ve 12. sinıflarda verilen alanla ilgili meslek dersleri sayısı ( seçmeli ders saatleri hariç ) 44 saat iken bu durum teknik 
programlarda 20 saate düşmektedir. Dolayısı ile muhasebe eğitimi veren meslek liselerinde meslek programının uygulanması durumunda meslek dersleri daha ağırlıklı olacak, teknik programın uygulanması durumunda ise kültür dersleri (matematik, fizik, kimya vb.) daha ağırlıklıolacaktır. $\mathrm{Bu}$ seçim okul idaresi tarafından öğrenci yapısına göre belirlenebilecektir.Meslek liselerinde verilen muhasebe dersleri ve modülleri Tablo 7'de yer almaktadir.

Tablo 7. Meslek Liselerinde Verilen Muhasebe Dersleri Ve Modülleri

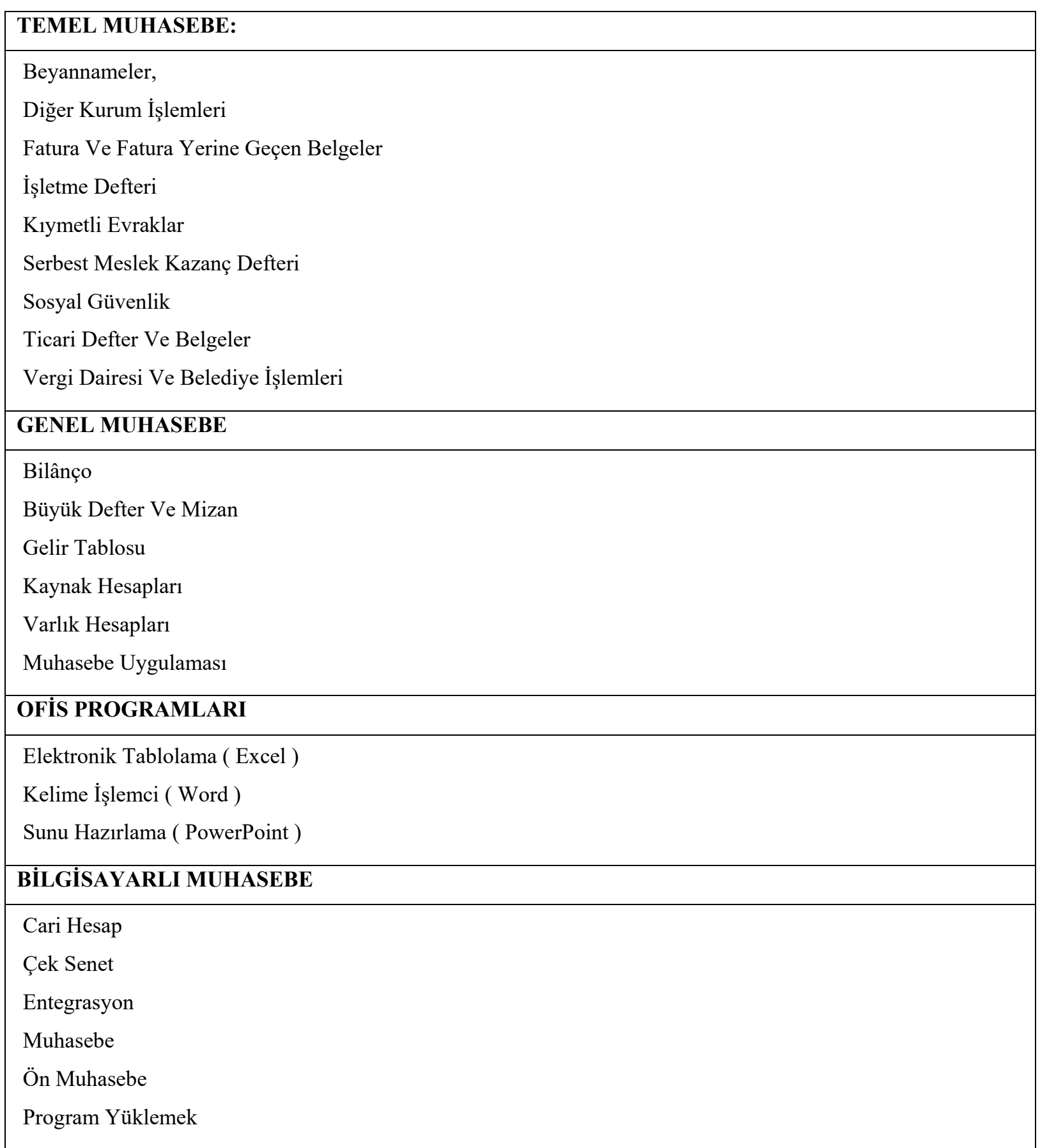

Kaynak: (http://www.megep.meb.gov.tr/?page=moduller, 2018 ) 


\section{ORTAÖĞRETIMM MESLEK DERSLERININ IÇERIKLERİ VE SEKTÖR BEKLENTILERINIIN KARŞILAŞTIRILMASI}

Ortaöğretim kurumlarında verilen muhasebe dersleri öğrenciye pratikte beklenen kazanımları ne kadar veriyorsa ders programları o kadar işlevsel olur ve bekleneni karşılar. İş bulma sitelerinden elde ettiğimiz ve çalışmamızda belirttiğimiz işverenlerin lise düzeyindeki meslek mensuplarından bekledikleri özellikler ve meslek liselerinde verilen meslek dersleri karşılaştırıldığında karşımıza şöyle bir tablo çıkmaktadır.

Tablo 8. Mesleki Bilgi Düzeyinde Beklentiler Ve Müfredattaki Ders Karşılaştırmaları

\begin{tabular}{|lll|}
\hline Mesleki Bilgi Düzeyinde beklentiler & Beklentiyi karşılayan dersler & Sınıf \\
\hline Muhasebe paket programı kullanabilme & Bilgisayarlı muhasebe dersi & 11 \\
\hline Ofis programlarını iyi seviyede kullanabilme & Bilgisayarda ofis dersi & 10 \\
\hline Beyanname verebilme & Temel Muhasebe dersi & 10 \\
\hline Tek düzen hesap planına hakimiyet & Genel Muhasebe dersi & 11 \\
\hline Genel muhasebe bilgisine sahip olma & Temel/ Genel Muhasebe dersi & $10 / 11$ \\
\hline Muhasebe süreçlerinde tecrübe & Genel Muhasebe dersi & 11 \\
\hline Dönem sonu muhasebe işlemlerine hakimiyet & Genel Muhasebe dersi & 11 \\
\hline
\end{tabular}

Meslek elemanından beklenen iş tanımları incelendiğinde ise mal ve hizmet alış ve satış belgelerinin muhasebeleştirilmesi, fatura, gider pusulası, perakende satış fişleri, dekont, makbuz, banka ekstreleri v.b. tüm belgeleri tasnif edilmesi, dosyalanmasi, muhasebe kayıtlarının tutulması, banka ve kredi kartı hareketleri, çek-senet ya da nakit olarak yapılan tahsilâtların, ödemelerin muhasebeleştirilmesi, personel dosyalarının hazırlanması ve personel giriş çıkış kontrollerinin yapılması, personel maaş hesaplamalarının yapılması, SGK (Sosyal Güvenlik Kurumu) bildirgeleri verilmesi, cari hesap kayıtlarını gerçekleştirilmesi, dönem sonu muhasebe işlemlerinin yapılması, beyannamelerin düzenlenmesi ve verilmesi, hesapların gerek kendi içinde, gerekse çalışılan kurumlarla mutabakatının yapılması gibi iş tanımları Genel Muhasebe, Temel Muhasebe ve Bilgisayarlı Muhasebe derslerinin ders içeriklerini kapsadı̆̆ını görmekteyiz.

Burada dersleri kesin bir çizgi ile ayırmak mümkün değildir. Çünkü bu dersler birbirlerini tamamlayan derslerdir. Örneğin Temel muhasebe; fatura ve fatura yerine geçen belgeleri, beyannameleri, ücret hesaplamalarını, işletme defteri ve serbest meslek kazanç defteri gibi konuları içermekte iken, Genel muhasebe Temel muhasebe bilgi ve belgelerine dayalı olarak tek düzen hesap planı, bilanço, gelir tablosu, mizan, defteri kebir, yevmiye defteri, dönem sonu işlemleri gibi kayıtları ve raporları içermektedir. Genel muhasebedeki kayıtların belgeleri ve hesaplamaları Temel muhasebede verilmektedir. Aynı zamanda bu bilgilerin program üzerinde uygulaması bilgisayarlı muhasebe dersinde yapılmaktadır. Dolayısı ile dersler birbirlerini tamamladığı için iş tanımları birkaç dersin içeriğini kapsamaktadır. 
Lise düzeyinde mesleki yeterlilik anlamında aranan kriterleri genel olarak Temel muhasebe, Genel muhasebe, Bilgisayarlı muhasebe ve ofis programları dersleri kapsamaktadır.Ayrıca istenen kriterleri sağlayan dersleri destekleyen mesleki matematik ve klavye gibi meslek dersleri de verilmektedir. Bunun yanı sıra seçmeli olarak maliyet muhasebesi, diş ticaret muhasebesi, şirketler muhasebesi gibi daha üst düzey ve spesifik konuları içeren derslerde verilebilmektedir. Genel itibari ile karşılaştırma yapılan ders programları ile beklentiler ve iş tanımları örtüştüğü söylenebilir.

\section{MESLEK DERSLERINIIN ÖĞRENCİLER ÜZERİNDEKİ KALICILIĞI VE ÖĞRENIM DÜZEYİNİN BELİRLENMESINE YÖNELİK BİR ARAŞTIRMA}

Meslek liselerinde verilen meslek derslerinin genel anlamda sektörün beklentilerini karşıladığ 1 ve iş tanımları ile örtüştüğü görülmektedir. Ancak verilen meslek derslerinin öğrenciler üzerinde ne derece etkili ve kalıcı olduğu konusu da önem arz etmektedir. Zira verilen eğitim öğrenciler tarafından yeterli seviyede kavranamıyorsa, öğrenciler sektörün istediği niteliklerden mahrum olarak mezun olacak, bu da iş bulma potansiyellerini olumsuz etkileyecektir.

$\mathrm{Bu}$ amaçla Erzurum merkez ilçelerinde muhasebe eğitimi alan 86 son sınıf muhasebe öğrencisinden 68'ine işverenlerin lise düzeyinde muhasebe mezunlarından bekledikleri iş tanımlarından oluşan 12 soruluk bir anket uygulanmış ve öğrencilerin ne düzeyde bu konuları öğrenmiş olduğu belirlenmeye çalışılmıştır. Anketin son sınıftaki öğrencilere uygulanmasının sebebi öğrencilerin muhasebe meslek derslerinin tamamını görmüş olmalarıdır.

Uygulanan anket çalışmasında verilen cevaplar ve yüzdelik dağılımları şöyledir.

Tablo 9: Beklenen iş tanımlarının öğrenci düzeyinde kavranma düzeyi

\begin{tabular}{|c|c|c|c|c|c|c|c|c|c|c|}
\hline \multirow[t]{2}{*}{ BEKLENEN İŞ TANIMLARI } & \multicolumn{2}{|l|}{ Hiç } & \multicolumn{2}{|c|}{$\begin{array}{l}\text { Çok az } \\
\text { düzeyde }\end{array}$} & \multicolumn{2}{|c|}{ Kararsızım } & \multicolumn{2}{|c|}{ İyi düzeyde } & \multicolumn{2}{|c|}{$\begin{array}{l}\text { Çok iyi } \\
\text { düzeyde }\end{array}$} \\
\hline & Kişi & $\%$ & Kişi & $\%$ & Kişi & $\%$ & Kişi & $\%$ & Kişi & $\%$ \\
\hline $\begin{array}{l}\text { Herhangi bir muhasebe programın } \\
\text { kullanabilirim. ( LOGO, ETA, } \\
\text { LUCA vb) }\end{array}$ & 0 & 0 & 13 & 19,12 & 16 & 23,53 & 33 & 48,53 & 6 & 8,82 \\
\hline TOPLAM & \multicolumn{4}{|c|}{$\% 19,12$} & & & \multicolumn{4}{|c|}{$\% 57,35$} \\
\hline $\begin{array}{l}\text { Ofis programlarını ( excell, word, } \\
\text { powerpoint } \mathrm{vb} \text {.) kullanabilirim. }\end{array}$ & 0 & 0 & 22 & 32,35 & 17 & 25 & 20 & 29,41 & 9 & 13,24 \\
\hline TOPLAM & \multicolumn{4}{|c|}{$\% 32,35$} & & & \multicolumn{4}{|c|}{$\% 42,65$} \\
\hline $\begin{array}{l}\text { Beyanname düzenleyebilirim. } \\
\text { (KDV, muhtasar, gelir, kurumlar } \\
\text { vb ) }\end{array}$ & 3 & 4,41 & 23 & 33,82 & 19 & 27,94 & 20 & 29,41 & 3 & 4,41 \\
\hline TOPLAM & \multicolumn{4}{|c|}{$\% 38,23$} & & & \multicolumn{4}{|c|}{$\% 33,82$} \\
\hline Tek düzen hesap planına hakimim. & 1 & 1,47 & 13 & 19,12 & 20 & 29,41 & 30 & 44,12 & 4 & 5,88 \\
\hline
\end{tabular}




\begin{tabular}{|c|c|c|c|c|c|c|c|c|c|c|}
\hline TOPLAM & \multicolumn{4}{|c|}{$\% 20,59$} & \multirow[b]{2}{*}{21} & \multirow[b]{2}{*}{30,88} & \multicolumn{4}{|c|}{$\% 50$} \\
\hline $\begin{array}{l}\text { Dönem sonu muhasebe işlemlerini } \\
\text { yapabilirim. }\end{array}$ & 6 & 8,82 & 23 & 33,82 & & & 16 & 23,53 & 2 & 2,94 \\
\hline TOPLAM & \multicolumn{4}{|c|}{$\% 42,64$} & & & \multicolumn{4}{|c|}{$\% 26,47$} \\
\hline $\begin{array}{l}\text { Muhasebede kullanılan belgeler } \\
\text { hakkında yeterli bilgim var. ( } \\
\text { fatura, sevk-taşıma irsaliyesi, gider } \\
\text { pusulası, müstahsil makbuzu vb.) }\end{array}$ & 2 & 2,94 & 13 & 19,12 & 17 & 25 & 26 & 38,24 & 10 & 14,71 \\
\hline TOPLAM & \multicolumn{4}{|c|}{$\% 22,06$} & & & \multicolumn{4}{|c|}{$\% 52,95$} \\
\hline $\begin{array}{l}\text { Alış ve satış faturalarını } \\
\text { muhasebeleştirebilirim. }\end{array}$ & 1 & 1,47 & 7 & 10,29 & 8 & 11,76 & 37 & 54,41 & 15 & 22,06 \\
\hline TOPLAM & \multicolumn{4}{|c|}{$\% 11,76$} & & & \multicolumn{4}{|c|}{$\% 76,47$} \\
\hline $\begin{array}{l}\text { sevk-taşıma irsaliyesi, gider } \\
\text { pusulası, müstahsil makbuzu, } \\
\text { dekont, vb. diğer belgeleri } \\
\text { muhasebeleştirebilirim }\end{array}$ & 5 & 7,35 & 17 & 25 & 26 & 38,24 & 15 & 22,06 & 5 & 7,35 \\
\hline TOPLAM & \multicolumn{4}{|c|}{$\% 32,35$} & & & \multicolumn{4}{|c|}{$\% 29,41$} \\
\hline Maaş hesaplamalarını yapabilirim. & 8 & 11,76 & 22 & 32,35 & 23 & 33,82 & 10 & 14,71 & 5 & 7,35 \\
\hline TOPLAM & \multicolumn{4}{|c|}{$\% 44,11$} & & & \multicolumn{4}{|c|}{$\% 22,06$} \\
\hline $\begin{array}{l}\text { SGK ( sosyal güvenlik kurumu ) } \\
\text { bildirimlerini verebilirim. }\end{array}$ & 8 & 11,76 & 11 & 16,18 & 30 & 44,12 & 13 & 19,12 & 6 & 8,82 \\
\hline TOPLAM & \multicolumn{4}{|c|}{$\% 27,94$} & & & \multicolumn{4}{|c|}{$\% 27,94$} \\
\hline $\begin{array}{l}\text { Çek, senet ve nakit tahsilat } \\
\text { kayıtlarını yapabilirim. }\end{array}$ & 1 & 1,47 & 11 & 16,18 & 21 & 30,88 & 25 & 36,76 & 10 & 14,71 \\
\hline TOPLAM & \multicolumn{4}{|c|}{$\% 17,65$} & & & \multicolumn{4}{|c|}{$\% 51,47$} \\
\hline Cari hesap kayıtlarını yapabilirim. & 1 & 1,47 & 14 & 20,29 & 19 & 27,94 & 23 & 33,82 & 11 & 16,18 \\
\hline TOPLAM & \multicolumn{4}{|c|}{$\% 21,76$} & & & \multicolumn{4}{|c|}{$\% 50$} \\
\hline GENEL ORTALAMA & \multicolumn{4}{|c|}{$\% 27,54$} & \multicolumn{2}{|c|}{$\frac{1}{\% 29,08}$} & \multicolumn{4}{|c|}{$\% 43,38$} \\
\hline
\end{tabular}

Çalışmada iyi düzeyde ve çok iyi düzeyde kategorileri birleştirildiğinde öğrencilerin beklenen iş tanımlarından \%76,47 ile en yüksek düzeyde alış ve satış faturalarınınmuhasebeleştirilmesi becerisini elde ettikleri görülmektedir. Diğer kazanımların elde edilme oranları sirası ile \%57,35 ile muhasebe programı kullanma, \%52,95 ile muhasebede kullanılan belgeler hakkında bilgi sahibi olma, \%51,47 ile çek, senet ve nakit tahsilât kayıtları, \%50 ile tek düzen hesap planı hâkimiyeti ve cari hesap kayıtlarını yapabilme, $\% 42,65$ ile ofis programlarını kullanabilme, \%33,82 ile beyanname düzenleyebilme becerileridir. En az düzeyde ise \%22,06 ile maaş hesaplarını yapabilme, \%26,47 ile dönem sonu muhasebe işlemlerini yapabilme, \%27,94 ile SGK bildirimlerini 
verebilme ve \%29,41 ile sevk-taşıma irsaliyesi, gider pusulası, müstahsil makbuzu, dekont, vb. diğer belgeleri muhasebeleştirebilme yer almaktadır.

Genel ortalamalara bakılınca öğrencilerin \%27,54'ü istenen kazanımları ya hiç elde edemediğiya da çok az düzeyde elde ettiği, \% 43,38'i ise toplam kazanımları iyi düzeyde yada çok iyi düzeyde elde ettiği görülmektedir.

\section{SONUÇ}

Yoğun rekabet ortamında ülkeleri gelişmiş ülke seviyesine çıkaran ve rakiplerine avantaj sağlayan en önemli anahtar, ülkelerin geleceklerini oluşturan genç nesillerinin iyi bir eğitim almasıdır. Özellikle geleceğini planlayan ve şekillendiren gelişmiş veya gelişme arzusunda olan ülkeler gelecekte ihtiyaç duyacağı yetişmiş meslek elemanı gereksinimini bu günden yetiştirmesi gerekmektedir. İyi bir meslek elemanı iyi bir eğitimle, iyi bir mesleki eğitim de çağın ve sektörün ihtiyaç duyduğu kazanımları bireylere kazandıran müfredatla olabilmektedir.

$\mathrm{Bu}$ bağlamda ülkemizde verilen muhasebe eğitiminin sektör beklentilerini karşılama konusunda yaptığımız incelemede verilen derslerin genel olarak istenen mesleki şartları teorik anlamda karşıladığı ortaya çıkmaktadır. Ancak öğrencilere yapılan anket çalışmasının neticesinde istenen kazanımların sadece \%43,38 ini öğrenciler iyi düzeyde kavrandıklarını ifade etmiş, \%27,54 ü istenen kazanımları ya hiç elde edememiş ya da çok az düzeyde elde etmiş, \%29,08 ise herhangi bir fikir beyan edememişlerdir. Bu oranların gerçek bir iş deneyiminde daha da aşağılara çekileceği aşikârdır. Çünkü öğrenciler henüz gerçek bir iş deneyimi yaşamamışlardır. Ayrıca uygulanan anket çalışması ortaöğretim muhasebe eğitimindeki kazanımlara dönük olduğu için ve öğrencilerin ara eleman olarak yetiştirilmeleri amaçlandığından raporlama ve finansal tabloların analizi ile ilgili sorular bulunmamaktadır.

Eğitimde pratik uygulamaların daha da arttırılması ve teorik eğitimin pratiğe dökülmesi kalıcılık ve öğrenme anlamında daha sağlıklı olacaktır. Ayrıca yapılan çalışmada ders içerikleri incelendiğinde istenen beklentilerin yanında çok çeşit ve ayrıntının mevcut olduğu görülmüştür. Ayrıntının ve çeşitliliğin azaltılması, içeriklerin öğrenci seviyelerine göre sadeleştirilmesi, örnek ve uygulamalara ağırlık verilmesi kavrama düzeylerinin arttırılmasına yardımcı olacaktır. Aynı zamanda hızlı değişen iş ihtiyaçlarını karşılaması için müfredatın sürekli güncellenmesi eğitim kalitesini arttıracaktır.

Hemen hemen her iş ilanında meslek elemanından beklenen ofis programları kazanımlarını veren ofis programları dersinin 2018-2019 eğitim ve öğretim yılından itibaren 2 saat okutulması yerine daha önce olduğu gibi 4 saat olması öğrencilerin uygulama anlamında daha çok pratik yapmasına imkan vereceğinden daha sağlıklı olacaktır.

Maliyet muhasebesi, şirketler muhasebesi, dış ticaret muhasebesi gibi daha spesifik ve uzmanlık gerektiren konuları içeren seçmeli dersler ise verilecekse eğer oldukça sadeleştirilerek verilmeli ya da Anadolu meslek programlarının devamı niteliğinde olan meslek yüksek okullarında veya lisans düzeyinde, alanında uzmanlaşmak isteyen bireylere verilmelidir. 
Ayrıca sektörün meslek elemanlarında beklediği kişisel gelişim düzeyindeki beklentilerinin kazandırılması için akademik derslerin ağırlığının azaltılarak öğrencilerin kendilerini daha iyi ifade etmelerini sağlayacak, kişisel ve sosyal yönlerini, iletişim becerilerini, özel becerilerini geliştirecek, kişisel gelişimlerini arttıracak, spor veya herhangi bir sanatsal kazanım sağlayacak derslerin verilmesi okula bağlılığı ve verimliliği arttıracaktır.

Ders programlarında temel ve meslek programı ayrımının yapılması ve meslek programlarında meslek derslerinin ağırlıklı olması, meslek programlarının ara eleman ihtiyacını karşılamaya yönelik olduğunu, teknik programlarda ise kültür derslerinin ağırlıklıolması, teknik programlarınyüksek öğrenime, üst düzey meslek elemanı yetiştirmeye yönelik olduğunu göstermektedir. Ortaöğretim muhasebe eğitiminde teknik ve meslek program ayrımı öğrenci seviyesi ve amaç farklılıklarından dolayı eğitim anlamında olumlu bir farklılık oluşturmaktadır. Ancak bunun yanında İktisadi İdari Bilimler, İşletme, iktisat Fakülteleri gibi alan ile alakalı bölümler için teknik programlara ek puanların verilmesi, bu bölümleri akademik olarak daha iyi öğrencilerin tercih etmelerini ve dolayısıyla meslek liselerinin daha kaliteli bir yapıya dönüşmesini sağlayacaktır.

\section{KAYNAKLAR}

Akbulut, Halim.- Pekkaya, Mehmet.-Aksakaloğlu, Hakan.(2014), "Meslek Mensuplarının Bakış Açısıyla Ticaret Meslek Liselerindeki Muhasebe Eğitimi: Bursa İli Üzerine Bir Uygulama", Muhasebe ve Finansman Dergisi, sayı: 62, Nisan, ss. 73-92

Alkan, Gönül, (2015), “İşletmelerin ÖnlisansMuhasebe Eğitiminden Beklentileri: İzmir’de Bir Araştırma”, Muhasebe Bilim Dünyası Dergisi, 17 (1): Mart, ss. 137-158

Bekçi, İsmail.- Titiz, İsmet.- Ömürbek, Nuri. (2006), "Muhasebe Eğitimi Alan Öğrencilerin Bilgisayarlı Muhasebe Dersine Bakış Açılarına İlişskin Bir Araştırma", Muhasebe ve Finansman Dergisi, Say1. 29, Ocak. ss. 166-175.

Bonwell, Charles C. -Eison, James A. (1991), Active Learning: Creating Excitement In The Clasroom, ASHE-ERIC Higher Education Report No: 1, The George Washington University, School of Educationand Human Development, Washington D.C.

Byrne, Marran -Flood, Barbara, (2005), “A Study of Accounting Students' Motives, ExpectationsAndPreparednessForHigherEducation", Journal of FurtherandHigherEducation, 29 (2), ss.111-124.

ChengKai-Wen, (2007), "TheCurriculum Design in Universities From The Perspective Of Providers in Accounting Education”, Education, 127 (4), ss. 581-590.

Cottell, P.G.J. - Milis, B.J. (1993), “CooperativeStructuresInTheInstruction Of Accounting”, IssuesAccount Edu. Cilt 8, Say1 1, ss. 40-60.

Çaldağ, Yurdakul.- Bayırlı, Rıdvan.- Altay, Adem (2004), "Muhasebe Doktora Programlarının Etkinliğinin Artırılması", XXIII. Türkiye Muhasebe Eğitimi Sempozyumu, Mayıs, Antalya 
Çiftçi, Yavuz - Çemrek, Nermin (2018), "Ticaret Meslek Liselerinde Muhasebe Eğitimi: Muğla İli'ndeki Meslek Liseleri Üzerine Bir Araştırma", Ömer Halisdemir Üniversitesi İktisadi ve İdari Bilimler Fakültesi Dergisi, 11(1)ss. 192-208

Erol, Mikail - Atmaca, Metin (2015), "Ticaret Meslek Liselerindeki Muhasebe Eğitiminin Tarihi Gelişimi”, Muhasebe ve Finans Tarihi Araştırmaları Dergisi, (8),ss. 79-100.

Erol, Mikail -Gülgün Erkan, (2008), "Lisans Düzeyinde Muhasebe Eğitimi Alan Öğrencilerin Başarılarını Etkileyen Faktörlerin Belirlenmesine Yönelik Biga İïF'de Bir Araştırma", Karamanoğlu Mehmet Bey Üniversitesi İ̈BF Dergisi, Sayı:14, ss.284301.

HoşgörürVural - Gezgin Gamze, (2004), "Ekonomik ve Sosyal Kalkınmada Eğitim”, http:// efdergi.yyu.edu.tr/makaleler/c1lt_II/Vural_hosgor.doc. (20.04.2018)

Kalmış, Halis -Yılmaz, Berna Burcu (2004), "Lisans Seviyesindeki Muhasebe Eğitiminin Mevcut Durumu Ve Geliştirilmesi İçin Yapılması Gereken Geliştirmeler”,. XXIII. Türkiye Muhasebe Eğitimi Sempozyumu, Antalya.

Kırlığlu, Hilmi -Gökgöz, Ahmet (2011), "Ticaret Meslek Liselerinde Muhasebe Eğitimi Alan Öğrencilerin Stajyerlikte Karşılaştıkları Problemler Ve Çözüm Önerileri: İstanbul Örneği”, ZKÜ Sosyal Bilimler Dergisi, Cilt 7, Sayı 13, ss. 131-146

Mısırlıoğlu, İsmail Ufuk, (2008), "TeachingAnd Learning ExperienceIn Accounting Education: A UK Perspective", Muhasebe Bilim Dünyası Dergisi (MODAV), 10 (4), ss. 19-35.

Özdoğan, Seher Turanlı (1978), Muhasebe Öğretim Metodları El Kitabı, Ankara:

Özkan, Fatih - Aksoy, Cenk (2015), "Ticaret Meslek Lisesi Muhasebe Bölümü Öğrencilerinin İşletmelerde Beceri Eğitimi Uygulaması, Gaziantep İlinde Bir Alan Araştırması", Bartın Üniversitesi İ.İ.B.F. Dergisi, Cilt: 6 Say1: 12, ss. 283-305

Şengel, Salim (2010), "Sürekli Muhasebe Meslek Eğitiminin Önemi ve Bir Değerlendirme", Muhasebe ve Finansman Dergisi, Say1: 47, Temmuz, ss. 81-94

Şişman, Ayşin (2008), “Osmanlı Devleti'nde Batılı Anlamda Mesleki Ve Teknik Eğitimin Doğuşu”, Uşak Üniversitesi Sosyal Bilimler Dergisi, 1/1, ss. 27-43

Zaif, Figen - Ayanoğlu, Yıldız, (2007), "Muhasebe Eğitiminde Kalitenin Arttırılmasında Ders Programlarının Önemi: Türkiye'de Bir İnceleme", Gazi Üniversitesi İktisadi ve İdari Bilimler Fakültesi Dergisi, 9/1, ss. 115- 136

\section{İnternet Kaynakları:}

http://mtegm.meb.gov.tr/meb_iys_dosyalar/2016_07/29122004_mte_stareji_belgesi_2014_20 18_1.pdf, (10.05.2018)

https://www.kariyer.net/is-ilanlari, (16.06.2018) 
http://www.iskur.gov.tr/tr-tr/anasayfa.aspx, (18.06.2018)

http://www.megep.meb.gov.tr/?page=ogretimProgramlari, (20.06.2018)

http://www.megep.meb.gov.tr/?page=moduller, (10.07.2018)

http://sgb.meb.gov.tr/meb_iys_dosyalar/2018_02/28093718_Faaliyet_Raporu_yayYn_28022 018_1707.pdf,( 15.05.2018)

http://sgb.meb.gov.tr/meb iys_dosyalar/2017_09/08151328 meb istatistikleri_orgun_egitim _2016_2017.pdf, $(\overline{1} 8.0 \overline{5} .2018)$

https://dokuman.osym.gov.tr/pdfdokuman/2017/osys/LYS/SayisalBilgiler11072017_.pdf, $(25.05 .2018)$ 